\title{
FORMATION OF SELF-CONCEPT OF EARLY ADOLESCENT BOYS AND GIRLS AS A FUNCTION OF ACADEMIC ACHIEVEMENT AND PARENTAL PROFESSION
}

\author{
Shahuria Enam, Md. Shariful Islam* and Kazi Imrul Kayesh \\ Department of Psychology, University of Rajshahi, Rajshahi, Bangladesh. \\ *Corresponding author (email: sharif.psy@gmail.com)
}

\begin{abstract}
The study conducted an empirical investigation on self-concept as related to gender, parental profession and academic achievement among early-adolescent boys and girls in various institutions of Rajshahi city. A total of 160 respondents constituted the sample of the study. A $2 \times 2 \times 2$ factorial design involving two levels of gender (boy/girl), two levels of parental profession (service/business) and two levels of academic achievement (high achiever/low achiever) were used. The results showed significantly higher self-concept of girls than boys. In case of academic achievement high achievers expressed significantly more positive self-concept than low achievers. In case of parental service, high achiever boys and high achiever girls expressed significantly more positive self-concept followed by their counterpart low achievers. In case of parental business, it was found that high achiever girls expressed significantly more positive self-concept than low achiever girls. However no significant mean difference was obtained between high achiever boys and low achiever boys in case of parental business. Thus, self-concept of young children was found to be determined by gender, parental profession and academic achievement during early adolescent stage.
\end{abstract}

Key words: Early-adolescence, self-concept, academic achievement.

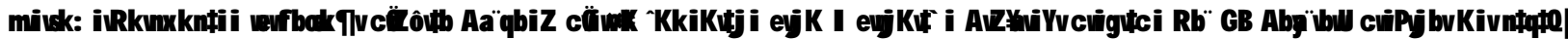

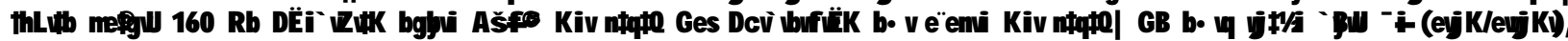

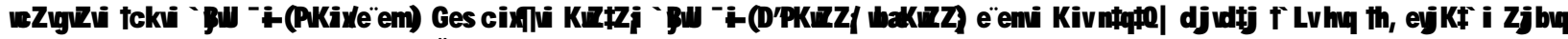

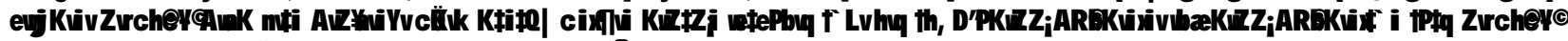
A vaK n

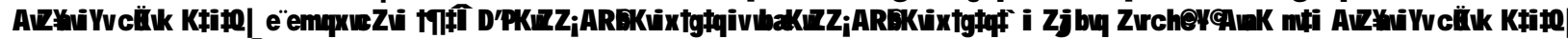

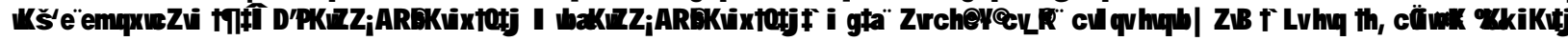

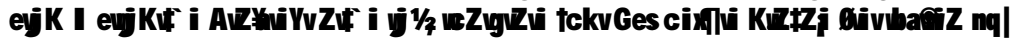

\section{Introduction}

A large number of previous researches (Hay et al. 1997; Marsh et al. 1999; Gonzalez Pienda et al. 2000; Nunez et al. 1998) suggested the relationship between academic achievement and self-concept of early adolescent boys and girls. Calsyn and Kenny (1977) showed that self-concept is a determinant of academic achievement whereas academic self-concept is a consequence of academic achievement. Again, prior achievement on subsequent self-concept has positive influence. Osborne and LeGette (1982) found that boys had significantly higher domain specific self-concept of physical appearance than the girls. But girls had better self-concept in behavioral social domains than the boys. Mboya (1994) observed higher self-concept of boys than girls in the domains of family, physical ability, physical appearance, musical ability and health but girls had higher self-concept in general school and emotional stability domains. Again, boys expressed higher levels of global self-concept than girls.
Wigfield et al. (1997) have offered a developmental perspective on the relation between self-concept and academic achievement. This developmental perspective has focused on the correlational and causal aspect of the relation between self-concept and academic achievement. In another study, Boulter (2002) used selfconcept as a predictor of academic achievement. Furthermore, age emerged as an important variable and supported the idea that total self-concept may predict academic performance but non-academic self-concept was negatively related with school achievement. Above all, academic self-concept is found strongly and positively related with general achievement as well as language, arts and mathematics. Again, parental influence plays an important role in the formation of self-concept. Parental influences are generally exerted through education, profession and family warmth. Demo et al. (1987) conducted an empirical study on parent-child relationship. The findings of the study showed that parental profession and education provide different feedback helpful for the formation of selfconcept. The findings also showed that parents may 
provide messages for their sons and daughters necessary for the formation of self-concept. Butler-Por (1987) conducted an investigation to explore the parental relationships with boys and girls for the formation of self-concept. The investigator identified parental influence as an important factor for developing selfconcept. The results showed that parents show greater attention and higher responsiveness to the achievements of their sons for the development of higher self-concept as compared to their daughters. These findings explained attention and responsiveness as a dynamic factor for the development of self-concept. The selfconcept of early adolescent boys and girls in sociocultural context of Bangladesh is a critical component.

The present study is an investigation on self-concept with reference to gender, parental profession and academic achievement of early adolescent boys and girls. The objectives of the study would be stated highlighting self-concept to assess the relationships between self concept and related variables such as gender, parental profession and academic achievement.

The study is a scientific approach to explain the relationship between self-concept and its related variables. Hence the rationale of the study consists in explaining self-concept in its various aspects. In addition, this study is an empirical investigation of selfconcept that would give a profile of different dimensions of self-concept in the context of Bangladesh. The study would help the parents and teachers to explore the academic performance of their children in the pursuit of knowledge in their academic fields. Lastly the study is a concerted effort to compile the discrete information of empirical findings about self-concept related with appropriate variables in a single investigation.

\section{Materials and Methods}

Sample: A total of 160 respondents constituted the sample of the study. They were selected using stratified random sampling procedure. These respondents were school students of early adolescent period. They were collected from different educational institutions of Rajshahi City. They were between 10 to 12 years old. They were interviewed one by one in their school. The sample was equally divided into boys and girls. Each group was again equally divided into high achiever and low achiever on the basis of their academic achievement. Each subdivision was again equally divided into service group and business group on the basis of their parental profession.
Measure: A Bengali version of Self Description Questionnaire I (SDQ-I) (Enam 2005) was used for collecting data. The original form of SDQ-I was proposed by Marsh (1990). This questionnaire contained 76 Likert-type items divided into 8 dimensions. These were physical ability, physical appearance, peer relation, parent relation, reading, mathematics, general school and general self. The total number of items included in SDQ-1 was 76. The highest score of SDQ-1 was 380 and the lowest 76. Hence, a score below 228 was considered as negative self-concept and a score on or above 228 was regarded as positive self-concept.

The co-efficient of correlation between Bengali total selfscore and English total self-score was estimated as 0.879. This correlation indicated the strength existing between Bengali version and original English version of SDQ-1. It meant that the Bengali translation from original English version was accurate and may be regarded as homogeneous. Reliability co-efficient of SDQ-1 of Bengali version was computed with 8 dimensions $(\mathrm{N}=360)$. The correlation between two forms of Bengali version was computed and the co-efficient of correlation was 0.64 . The equal length Spearman-Brown reliability co-efficient was computed $(\mathrm{N}=360)$ and it was 0.78 . Guttman split-half reliability was computed with odd and even numbers and $r$ was found 0.78 . All these reliability co-efficients were highly significant and indicated high reliability of the Bengali version of SDQ-1.

Design of the study and data collection: The present study used a $2 \times 2 \times 2$ factorial design. It involve two levels of gender (boys/girls), two levels of academic achievement (high achiever/low achiever) and two levels of parental profession (service/ business). After collecting the data analysis of variance was computed and the results were interpreted for the total scores of self-concept.

\section{Results and Discussion}

The analysis of results showed that main effects of gender and academic achievement were statistically significant (Table 1). A two-way interaction involving gender and academic achievement was also statistically significant. Again a three-way interaction involving gender, academic achievement and parental profession was also statistically significant. Further analysis of results (Table 2) showed that regardless of academic achievement and parental profession, girls had higher scores $(\mathrm{M}=330.00)$ than the boys $(M=302.52)$. This indicated a significantly higher self-concept of the girls than the boys. Moreover, regardless of gender and parental profession (Table 3), high achievers were found to have higher scores $(M=332.56)$ than the low achievers $(M=299.96)$. This indicated a significantly higher self-concept of high achievers than their low achiever counterparts. 
Table 1. ANOVA table showing the effects of gender and academic achievement on the scores of SDQ-I for measuring self-concept.

\begin{tabular}{|c|c|c|c|c|}
\hline Sources of variance & Sum of squares & Degrees of freedom & Mean Square & Variance Ratio \\
\hline Gender (A) & 30195.02 & 1 & 30195.02 & $29.43^{* *}$ \\
\hline Profession (B) & 783.22 & 1 & 783.22 & $0.76 \mathrm{~ns}$ \\
\hline Academic Achievement (C) & 42510.4 & 1 & 42510.4 & $41.44^{* *}$ \\
\hline $\mathrm{A} \times \mathrm{B}$ & 2.03 & 1 & 2.03 & $00 \mathrm{~ns}$ \\
\hline $\mathrm{A} \times \mathrm{C}$ & 14440.00 & 1 & 14440.00 & $14.07^{* *}$ \\
\hline $\mathrm{B} \times \mathrm{C}$ & 422.5 & 1 & 422.5 & $0.41 \mathrm{~ns}$ \\
\hline $\mathrm{A} \times \mathrm{B} \times \mathrm{C}$ & 8880.4 & 152 & 1025.76 & $8.66^{*}$ \\
\hline Within cell & 155916.4 & 159 & & \\
\hline Total & 253149.97 & & & \\
\hline$*=\mathrm{P}<0.05, * *=\mathrm{P}<0.01, \mathrm{~ns}=$ not significant. & & & \\
\hline
\end{tabular}

Table 2. Mean difference between boys and girls on the scores of self-concept in early adolescent stage.

\begin{tabular}{|c|c|c|c|c|c|c|c|}
\hline Comparison Groups & \multirow{2}{*}{ Mean Score } & Girls & Boys & $\mathrm{r}$ & $\frac{\mathrm{q} .95}{\mathrm{q} .99}$ & \multirow{2}{ms}{$/ n$} & Critical value \\
\cline { 3 - 7 } & & 330.00 & 302.52 & & 2.77 & 2.53 & $\frac{7.01}{3.64}$ \\
\hline Girls & 330.00 & & $27.48^{* *}$ & 2 & & & \\
\hline Boys & 302.52 & & & & & & \\
\hline
\end{tabular}

Table 3. Mean difference between high achiever and low achiever respondents on the scores of self-concept in early adolescent stage.

\begin{tabular}{|c|c|c|c|c|c|c|c|}
\hline \multirow[t]{2}{*}{$\begin{array}{l}\text { Comparison } \\
\text { Groups }\end{array}$} & \multirow[t]{2}{*}{ Mean Score } & $\begin{array}{c}\text { High } \\
\text { Achiever }\end{array}$ & Low Achiever & \multirow[t]{2}{*}{$\mathrm{r}$} & \multirow[t]{2}{*}{$\frac{\mathrm{q} .95}{\mathrm{q} .99}$} & \multirow[t]{2}{*}{$\sqrt{m s / n}$} & \multirow[t]{2}{*}{ Critical value } \\
\hline & & 332.56 & 299.96 & & & & \\
\hline High Achiever & 332.56 & & $32.6 * *$ & 2 & $\frac{2.77}{3.64}$ & 2.53 & $\frac{7.01}{9.21}$ \\
\hline Low Achiever & 299.96 & & & & & & \\
\hline
\end{tabular}
$* *=\mathrm{P}<0 \cdot 01$.

An inspection of the mean scores and their significant mean differences (Table 4) showed that in case of boys, high achiever respondents (M=309.32) expressed significantly higher positive self-concept as compared to the low achiever respondents $(M=295.72)$. Similarly, in case of girls, high achiever respondents $(M=355.80)$ showed significantly higher positive self-concept as compared to the low achiever respondents $(M=304.20)$. Between group comparisons, high achiever girls ( $M=355.80)$ showed significantly more positive self-concept as compared to high achiever boys $(\mathrm{M}=309.32)$. Similarly, low achiever girls $(\mathrm{M}=304.20)$ expressed significantly more positive self-concept than the low achiever boys $(\mathrm{M}=295.72)$.

Table 4. Mean differences on two-way interaction involving gender and academic achievement on the scores of self-concept in early adolescent stage.

\begin{tabular}{|c|c|c|c|c|c|c|c|c|c|}
\hline $\begin{array}{c}\text { Comparison } \\
\text { Groups }\end{array}$ & Mean score & $\begin{array}{r}\text { H.AG } \\
355.80\end{array}$ & $\begin{array}{l}\text { H.A.B } \\
309.32\end{array}$ & $\begin{array}{l}\text { L.A.G } \\
304.20\end{array}$ & $\begin{array}{l}\text { L.A.B } \\
295.72\end{array}$ & $\mathrm{r}$ & $\frac{q .95}{q .99}$ & $\sqrt{m s / n}$ & $\begin{array}{l}\text { Critical } \\
\text { value }\end{array}$ \\
\hline $\begin{array}{c}\text { High Achiever } \\
\text { Girl }\end{array}$ & 355.80 & & $46.48 * *$ & $51.6 * *$ & $60.08 * *$ & 4 & $\frac{3.63}{4.40}$ & 2.53 & $\frac{9.18}{11.13}$ \\
\hline $\begin{array}{c}\text { High Achiever } \\
\text { Boy }\end{array}$ & 309.32 & & & 5.12 & $13.6 * *$ & 3 & $\frac{3.31}{4.12}$ & 2.53 & $\frac{8.37}{10.42}$ \\
\hline $\begin{array}{c}\text { Low Achiever } \\
\text { Girl }\end{array}$ & 304.20 & & & & $8.48 *$ & 2 & $\frac{2.77}{3.64}$ & 2.53 & $\frac{7.01}{9.21}$ \\
\hline $\begin{array}{c}\text { Low Achiever } \\
\text { Boy }\end{array}$ & 295.72 & & & & & & & & \\
\hline
\end{tabular}

Note: Mean difference was computed using Newman-Keuls formula; $*=\mathrm{P}<0.05$, ${ }^{* *}=\mathrm{P}<0.01 ; \mathrm{r}=$ Number of steps between ordered scores; The critical values of q.95 and q.99 have been obtained from the distribution of studentized Range statistic (Winer 1971). 
Table 5. Mean differences among comparison groups between different levels of gender, parental profession and academic achievement on the scores of SDQ-I.

\begin{tabular}{|c|c|l|l|}
\hline Gender & Academic achievements & Service & Business \\
\hline \multirow{2}{*}{ Boy } & High Achiever & $316.30 \mathrm{a}$ & $302.35 \mathrm{~b}$ \\
\cline { 2 - 4 } & Low Achiever & $284.55 \mathrm{c}$ & $306.90 \mathrm{~b}$ \\
\hline \multirow{2}{*}{ Girl } & High Achiever & $347.65 \mathrm{~d}$ & $363.95 \mathrm{c}$ \\
\cline { 2 - 4 } & Low Achiever & $307.70 \mathrm{~b}$ & $300.70 \mathrm{~b}$ \\
\hline
\end{tabular}

Common subscripts do not differ significantly. Mean differences were computed using Newman-Keuls formula ( $\mathrm{P}<0.01)$.

An inspection of mean scores (Table 5) showed that high achiever boys with parental service $(\mathrm{M}=316.30)$ expressed significantly more attitudinal preference indicating a higher positive self-concept as compared to their counterpart respondents with parental business $(\mathrm{M}=302.35)$. But low achiever boys with parental business $(M=306.90)$ expressed significantly higher attitudinal preference indicating more positive selfconcept as compared to their counterpart respondents with parental service $(M=284.55)$. Thus an inverse relationship emerged between these comparison groups, suggesting an interaction effect which is graphically plotted in Fig. 1.

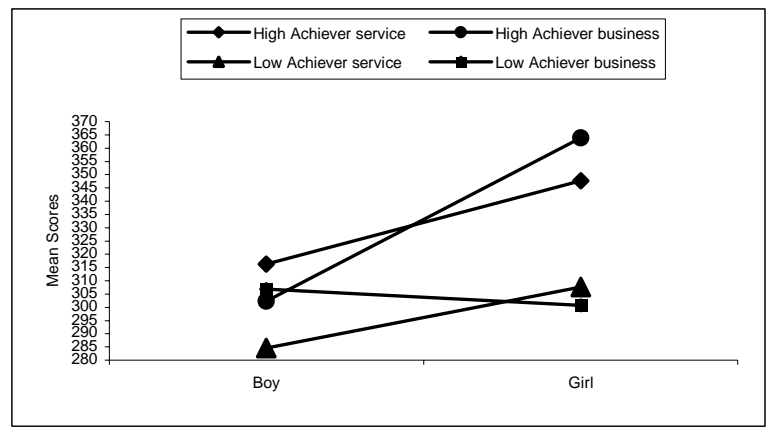

Fig. 1. Three-way interaction effects of gender, parental profession and academic achievement on the scores of self-concept.

Again, it was found that high achiever girls with parental business $(\mathrm{M}=363.95)$ expressed significantly more attitudinal preference indicating higher positive self-concept as compared to their counterpart respondents with parental service $(\mathrm{M}=347.65)$. But low achiever girls with parental service $(M=307.70)$ expressed significantly more attitudinal preference indicating higher positive self-concept as compared to their counterpart respondents with parental business $(M=300.70)$. Thus an inverse relationship emerged between these comparison groups, indicating also an interaction effect (Fig.1.)
Between group comparisons showed that in case of boys with parental service, high achievers $(M=316.30)$ expressed significantly higher positive self-concept than low achievers $(M=284.55)$. But in case of boys with parental business, the low achievers $(M=306.90)$ showed significantly more positive self-concept as compared to high achievers ( $\mathrm{M}=302.35)$. Again, in case of girls with parental service, the high achievers $(\mathrm{M}=347.65)$ expressed significantly more positive selfconcept as compared to the low achievers $(M=307.70)$. Similarly, in case of girls with parental business, the high achievers $(M=363.95)$ showed significantly more positive self-concept as compared to the low achievers $(\mathrm{M}=300.70)$. It was thus evident that the high achiever girls with parental business expressed the highest ( $M=363.95)$ self-concept followed by the high achiever girls with parental service $(M=347.65)$, high achiever boys with parental service $(M=316.30)$, low achiever girls with parental service $(M=307.70)$, low achiever boys with parental business $(M=306.90)$, high achiever boys with parental business ( $M=302.35)$, low achiever girls with parental business $(M=300.70)$ and the least self-concept was expressed by the low achiever boys with parental service $(M=284.55)$. It was therefore clear that gender, parental profession and academic achievement can influence the formation of positive self-concept of the students.

\section{Discussion}

This investigation was an empirical attempt to apply gender, academic achievement and parental profession to the study of self-concept in the social context of Bangladesh. The results showed that the effect of gender was statistically significant (Table 1). It was also found that girls expressed significantly higher positive self-concept as compared to the boys (Table 2). Previous studies (Marsh et al. 1983; Hattie 1992) have provided support in favour of these results. This finding may also be explained with reference to InternalExternal Comparison Theory of the development of self-concept (Marsh 1986) which states that the hierarchy of domain-specific ability self-concept may be 
conditioned by the developmental changes in boys and girls. Thus within individual perspective may cause variation in self-concept. Both boys and girls may develop different domains of interest due to withinindividual perspective. For example, differences between performance and self-concept ability may be increased with age. It is possible that boys and girls with same age experience different types of problems in their early adolescent stage. Girls experience adolescence at an early time than the boys. Thus important events occur in girls while boys experience the events of adolescence at a later period. These differences in experience during adolescence may account for differential amount of self-concept causing the girls to form higher self-concept than the boys.

Another important finding of the study showed that the effect of academic achievement was statistically significant (Table 1). It was found that high achievers expressed significantly higher positive self-concept as compared to low achievers (Table 3 ). This finding was exactly in the same line of the previous studies (Al-Izbi 1985; Nakadi 1995; Abdul Khalik 1996). It is said that education is a significant step to increase the selfconcept of boys and girls. Parents are very ambitious about their children. High achiever boys and girls are capable to fulfill the ambition of their parents. Moreover, high achiever students have higher levels of aspiration. They have fewer failures in different stages of education. Instead, they are rewarded for their superior achievement. All these activities are helpful to increase self-esteem, self-regard and social status. These may account for higher positive self-concept for the high achiever students as compared to the low achiever students.

Several important and significant findings relating the relationship between self-concept and proposed variable have emerged in two- and three-way analyses of variance. Thus a significant interaction effect was found between gender and academic achievement (Table 1). It was found that high achiever boys expressed significantly higher positive self-concept as compared to low achiever boys (Table 4). Similarly, high achiever girls expressed significantly higher positive self-concept as compared to low achiever girls. But both high achiever and low achiever girls expressed significantly higher positive self-concept as compared to the high and low achiever boys. These findings clearly showed that gender and academic achievement play an important role as moderating variable in the development of positive self-concept in early adolescent stage of life span. Moreover, these findings may be explained with reference to situational factors such as family, environment and school environment of the respected groups. Several studies (Dishion and Kavanagh 2001; Raboteg-Saric et al. 2001; Barber et al. 2003; Henderson et al. 2006) reported effects of family functioning on self-concept and identified the severity of adolescent externalizing problem. These findings revealed strong and direct relationships between family functioning and self-concept. The findings of the present study may be understood with reference to these previous results. The adolescent externalizing problems come from family functioning and school environment. In Bangladesh, economic contingency is found to work as a barometer in familial understanding between members such as parents, children and other adult person in the family. The confluence of these psychological functioning helps the children to develop self-concept in a specific manner. In the present study, it was important to note that majority of the parents of the respondents were with high economic standard in the society. Again other parents of the remaining respondents were established business magnets in the society. In a word, the study used a sample representing high educational and economic status. These familial atmospheres might have great impact on the boys and girls in their early adolescent stage directing towards the formation of positive self-concept.

Another important finding of the study was that a threeway interaction effect was statistically significant (Table 1). This indicated that gender, parental profession and academic achievement jointly produced a positive impact for the formation of self-concept in early adolescent stages of life span. It was found that high achiever boys with parental service expressed significantly higher positive self-concept as compared to high achiever boys with parental business (Table 5). But the low achiever boys with parental business expressed significantly higher positive self-concept as compared to the low achiever boys with parental service. These findings showed that self-concept of high achiever boys was influenced by parental service. But the self-concept of low achiever boys was influenced by parental business. In such cases parental service for high achiever boys and parental business for low achiever boys emerged as moderating factor of self-concept. It may be said that service as the parental profession has increased the self-esteem of boys resulting in the formation of high positive self-concept. But parental business has provided higher self-esteem to the low achiever boys resulting in the formation of high positive self-concept. This interpretation is in agreement with the findings of Khan et al. (2001), Adamson (2003), Manuel et al. (2003) and Shields et al. (2006). 
In case of girls, however, a converse relationship was evident. It was found that the high achiever girls with parental business expressed significantly higher positive self-concept as compared to the high achiever girls with parental service (Table 5). Again, the low achiever girls with parental service showed significantly higher selfconcept as compared to the low achiever girls with parental business. It was thus evident that the selfconcept of high achiever girls was dominated by parental business. But the self-concept of the low achiever girls was dominated by parental service. These findings importantly showed that the high achiever girls were positively related with parental business for the development of self-concept and the low achiever girls were positively related with parental service for the development of self-concept. These findings may be explained with reference to empirical data provided in previous investigations (Ross et al. 2007).

\section{Conclusion}

The present study may be regarded as an ideal investigation of self-concept based on standard methodology. A sufficient sample and a sound statistical technique may justify the generality of the findings. This study has used multiple indicators such as gender, parental profession and academic achievement for the study of self-concept in the adolescent stage of life span.

\section{References}

Abdul Khalik R. 1996. The relationship between self-esteem and academic achievement in a sample of social disadvantaged orphans. Unpub. Masters thesis. American University of Beirut, Lebanon.

Adamson L. 2003. Self-image, adolescence and disability. American J. Occupation Therapy 57: 578-581.

Al-Izbi M. 1985. Academic self-concept of high and low achievers and its relation to academic achievement and evaluation by others. Paper presented in the First General Conference in Psychology, Cairo, Egypt.

Barbar CN, Ball J and Armistead L. 2003. Parent-adolescent relationship and adolescent psychological functioning among African-American female adolescents: self- esteem as a mediator. J. Child Family Studies 12: 361-374.

Boulter LT 2002. Self-concept as a predictor of college freshman academic adjustment. College Student Journal 36(2): 234-246.

Butler-Por N. 1987. Underachievers in School: Issues and intervention. Chichester: John Wiley and Sons.

Calsyn R and Kenny D. 1977. Self-concept of ability and perceived evaluations by others: Cause or effect of academic achievement? J. Edu. Psychol. 69: 136-145.

Demo DH, Small SA and Savin-Williams RL. 1987. Family relations and the self-esteem of adolescents and their parents. J. Marriage Family 49: 705-715.
Dishion TJ and Kavanagh K. 2001. An ecological approach to family intervention for adolescent substance use. In: E. F. Wagner and H. B. Waldron (Eds.), Innovations in Adolescent substance abuse interventions (pp.127142). New York: Elsevier Science Ltd.

Enam S. 2005. Development of self-concept as related to gender, age and residential background in sociocultural context of Bangladesh. Unpub. PhD thesis. Department of Psychology, University of Rajshahi, Bangladesh.

Gonzalez-Pienda J.A, Nunez JC, Gonzalez-Pumariega S, Alvarez L, Roces C, Garcia M, Gonzalez P, Cabanach RG and Valle A. 2000. Autoconcepto, proceso de atribucion causal y metas academicas en ninos con y sin dificultades de aprendizaje. [self-concept, causal attribution process and academic goals in children with and without learning disabilities] Psicothema 12(4): 548-556.

Hattie J. 1992. Self-concept. Hillsdale, Erlbaum, NJ, USA.

Hay I, Ashman A and Van Kraayenoord C. 1997. Investigating the influence of achievement on selfconcept using and intra-class design and a comparison of the PASS and SDQ-1 self-concept tests. British Edu. Psychol. 67: 311-321.

Henderson CE, Dakof GA, Schwartz SJ and Liddle HA. 2006. Family functioning, self-concept and severity of adolescent externalizing problems. J. Child Family Studies.

Khan K, Riet G, Popay J, Nixon J and Kleijnen J. 2001. Phase 5: Study quality assessment. In: Undertaking Systematic Review of Research on Effectiveness. CRD's Guidance for those Carrying out or Commission Reviews.

Manuel JC, Balkrishnan R, Camacho F, Smith BP and Koman IA. 2003. Factors associated with self-esteem in preadolescents and adolescents with cerebral palsy. $J$. Adol. Health 32: 456-458.

Marsh HW 1986. Verbal and math self-concepts: An internal/external frame of reference model. American Edu. Res. J. 23: 129-149.

Marsh, H.W. 1990.The structure of academic self-concept: The Marsh/Shavelson model. J. Edu. Psychol. 82: 623-636.

Marsh HW, Byrne BM, and Yeung AS. 1999. Causal ordering of academic self-concept and achievement: Reanalysis of a pioneering study and revised recommendations. Edu. Psychol. 34: 154-157.

Marsh HW, Relich JD and Smith ID. 1983. Self-concept: The construct validity of interpretations based upon the SDQ. $J$. Per. Social Psychol. 45: 173-187.

Mboya MM 1994. Cross-cultural study of the structure and level of multi-dimensional self-concepts in secondary school students. School Psychol. Int. 15: 163-171.

Nakadi I. 1995. Self-concept in socially disadvantaged orphans: Comparison across grade level, gender, type of social disadvantage and relationship to academic achievement. Unpub. Masters thesis. American University of Beirut, Lebanon. 
Nunez JC, Gonzalez-Pienda JA, Garcia M, GonzalezPumariega S, Roces C, Alvarez L and Gonzalez MC. 1998. Estrategias de aprendizaje, autoconcepto y rendimiento academico. [Learning strategies, self concept and academic performance]. Psicothema 10(1): 97-109.

Osborne WL and LeGette HR. 1982. Sex, race, grade level, and social class differences in self-concept. Measure. Eval. Guid. 14: 195-201.

Raboteg-Saric Z, Rijavec M and Brajsa-Zganec A. 2001. The relation of parental practices and self-conceptions to young adolescent problem behaviours and substance use. Nordic J. Psychiatry 55: 203-209.

Ross JL, Mccauley E, Roeltgen D, Long L, Kushner H, Feuilian P and Cutler Jr. GB. 2007. Self-concept and behaviour in adolescent girls with turner syndrome: Potential estrogen effects. J. Clin. Endocrinol. Metabol. 81(3): 926-931.
Shields N, Murdoch A, Loy Y, Dodd KJ and Taylor NF 2006. A systematic review of the self concept of children with cerebral palsy compared with children without disability. J. Dev. Med. Child Neurol. 48: 151-157.

Wigfield A, Eccles JS, Yoon KS, Harold RD, Arbreton A, Freedman-Doan K and Blumenfeld P C. 1997. Change in children's competence beliefs and subjective task values across the elementary school years: A three year study. J. Edu. Psychol. 89: 451-569.

Winer BJ. 1971. Statistical Principles in Experimental Design ( $2^{\text {nd }}$ edn.). McGraw Hill Kogakusha Ltd. Japan. pp. 191-195.

Manuscript received on 14 May 2010 and revised on 7 January 2012 